\title{
A Review of Antimicrobial Properties of Alum and Sundry Applications
}

\section{Lawrence 0 Amadi*}

Department of Microbiology, Faculty of Science, Rivers State University, NkpoluOroworukwo, Port Harcourt, Nigeria

*Corresponding Author: Lawrence O Amadi, Department of Microbiology, Faculty of Science, Rivers State University, Nkpolu-Oroworukwo, Port Harcourt, Nigeria.
Received: February 25, 2020

Published: March 10, 2020

C) All rights are reserved by Lawrence $\mathbf{0}$

Amadi.

\begin{abstract}
Potassium aluminium sulphate (PAS) commonly referred to as 'potash alum (PA)', 'alum' or 'tawas' has recently drawn the attention of the scientific community as an efficient, safe and eco-friendly inorganic compound, commercially available and cost effective. It demonstrated a high propensity of antimicrobial activity in a variety of systems traditionally and scientifically. Several In vitro and In vivo studies report that alum individually or in synergism have antimicrobial properties against a broad spectrum of bacterial and fungal species and harnesses other activities beneficial to humans. This article has become crucial especially at a time when the world is bedevilled with antibiotic drug abuse resulting in antimicrobial resistance (AMR). Alum, however, has found applications in a wide spectrum of human activities such as pharmaceutical, cosmetic, food, textile and synthetic industries. This review presents an update of findings of this inorganic sulphate salt as an antimicrobial agent and miscellaneous applications.
\end{abstract}

Keywords: Alum; Antimicrobial Agent; Synergism; Antibiotic; Bacteria; Fungi

\section{Introduction}

Alum occurs naturally in rocks that are located in areas where sulphide materials and potassium-bearing minerals such as kalinite, alunite and leucite which on treatment with sulphuric acid results in crystals of alum. Alum is a general name for a class of double sulphates containing aluminum and such metals as potassium, ammonium, iron, etc. They are commonly found in India, Egypt, Nepal, Italy, Philippines and many parts of Asian countries. There are a variety of commercially available alums; soda alum, Ammonium alum, Chrome alum, Selenate alum, Alumen exsiccatum (dried alum), Aluminium sulphate (also called papermaker's alum, it is not technically alum but further processing and evaporation results in alum crystals) [1]. PAS or alum is an odourless, colourless crystalline solids with chemical formula, $\mathrm{KAl}\left(\mathrm{SO}_{4}\right)_{2}$. Based on the amount of water molecules, these hydrates are represented by the chemical formulae $\mathrm{KAl}\left(\mathrm{SO}_{4}\right)_{2} \cdot 12 \mathrm{H}_{2} \mathrm{O}$ or $\mathrm{K}_{2} \mathrm{SO}_{4} \cdot \mathrm{Al}_{2}\left(\mathrm{SO}_{4}\right)_{3} \cdot 24 \mathrm{H}_{2} \mathrm{O}$ [2].
Apart from the natural sourcing of alum, fabricated aluminum cans are currently recycled and chemically converted into an aluminium compound, hydrated PAS with an energy savings of $95 \%$ over refining and smelting bauxite ore. However, this provides an interesting means of green reduction of environmental pollution via conversion of waste to wealth [3].

Versatility of PAS individually or in synergism as; food preservative, medicine, water purifier, biotransformational and antimicrobial agents and sundry applications had been well documented [4-6]. The threat of AMR organisms over the decades has been accentuated by various anthropogenic activities such as heavy use and abuse of antibiotics, discharge of hospital and agricultural effluents resulting in serious socioeconomic challenges worldwide.

Thus, investigators are sourcing for other materials, such as substances of vegetative or mineral origin and natural products, as 
alternative to conventional antimicrobial agents. One of such natural products used for therapeutic purposes for centuries is white alum or PA [7]. Notable advantages for the use of alum include cost effectiveness, availability, nontoxicity, reusability and ecofriendliness [6]. The potency of alum as an antimicrobial agent had been visibly demonstrated over the years through the myriads of its beneficial activities and relevance in a broad spectrum of human research and development.

Recently, extensive research interest in this natural product has widened and opened new horizons and frontiers of knowledge in drug combination therapeutic strategy by boosting its efficacy. Combination strategies exploring the use of phytomedicinals with natural product and/or standard antimicrobials are essentially critical for creating a truly global and effective response to treat microbial infection and ameliorate AMR. Undoubtedly, combination strategy may improve drug performance by synergism which may proffer a better alternative to microbial resistance single drug/substance as this protocol is usually more effective at low dosage. Some major advantages of combination therapy are cost effectiveness, reduction of man-hour (as new drug is neither designed, formulated nor synthesized in the laboratory), less side effects associated with higher drug dosage can be minimized without compromising performance. However, encouraging the use of drugs in combination would improve the prevention and management of microbial infections therapy. The PAS shall be reviewed below in two (2) broad headings: Antimicrobial activity of alum and sundry applications.

\section{Antimicrobial activity of alum}

Antibacterial effect of alum

Among varieties of commercially available alums, potash alum is very much common both for household, pharmaceutical and medicinal applications. Alum concentrations at $(4.4-35.0 \mathrm{mg} /$ $\mathrm{mL}$ ) showed zones of inhibition which ranged from 0.005 $0.438 \mathrm{~cm}$ against $E$. faecalis, $0.019-0.421 \mathrm{~cm}$ against $E$. faecium, $0.011-0.455 \mathrm{~cm}$ against $S$. aureus, $0.013-0.430 \mathrm{~cm}$ against $E$. coli, and $0.025-0.485 \mathrm{~cm}$ against $K$. pneumoniae respectively at $24 \mathrm{hr}$ incubation. These results corroborate previous reports of 100 PPM alum solution as less than 1000 PPM alum or more [8]. Additionally, bactericidal effect of alum had been observed but the mechanism was not prominent. But it was postulations that it effect was to reduction in acidity or deleterious effects on bacterial cell wall. Another study determined the antibacterial activities of alum against four malodour-producing axillary bacterial flora ( $\mathrm{Mi}$ crococcus luteus (ATCC 49732), Staphylococcus epidermidis (ATCC 14990), Corynebacterium xerosis (ATCC BAA-1293) and Bacilus subtilis (ATCC 19659) as an alternative natural product for reducing axillary malodour. In vitro activity using broth dilution method for different concentrations (0.937-20.0mg/mL) on Luria-Bertani broth exhibited excellent inhibitory effects on all tested bacteria. The lowest MIC of alum was against C. xerosis, at $1.88 \mathrm{mg} / \mathrm{mL}$. M. luteus, B. subtilis and S.epidermidis showed a higher MIC of 3.75, 5.00 and $7.50 \mathrm{mg} / \mathrm{mL}$, respectively. These bacteria were completely inhibited at a concentration of $7.50 \mathrm{mg} / \mathrm{mL}$ [7]. Thus, antibacterial effects of alum against axillary malodour-producing bacteria could be recommended and used either directly by topical application or as an active ingredient in deodorants and antiperspirants.

Another study also, observed that white alum was potent against Escherichia coli 0157:H7 at a concentration above 1\% (p $<0.05$ ). Such effect was dose and time dependent as well as with other disinfectants. Strong antibacterial activity of white alum compared with control was shown against tested bacterium and could be used as an inhibitor of bacterial growth [9].

In a recent work attempt was made to provide some experimental proof of bioactivity of some of these G-R minerals (Lemnian Earth, Samian Earth and alum), by investigating their antibacterial action. They were tested against specific pathogens, one Gram negative (Pseudomonas aerugenosa) and one Gram positive (Staphylococcus aureus) bacterium. The results showed varying degrees of antibacterial action with the alum group mineral being the most effective [10]. Bacterial isolates from oysters treated with PAS exhibited broad spectrum antibacterial potency against Gram negative and Gram positive by in-vitro susceptibility tests but more efficacious by agar well diffusion (AWD) method. High levels of sensitivity on Proteus sp (18.0mm), Bacillus subtilis and Staphylococcus aureus $(17.0 \mathrm{~mm})$, Escherichia coli and Klebsiella species $(16.0 \mathrm{~mm})$ and Pseudomonas aeruginosa and Vibrio species $(13.0 \mathrm{~mm})$ were demonstrated respectively [11].

\section{Synergism with plant extract}

Synergistic effect has been shown by alum with various plant extracts. A combination therapeutic strategy with aqueous extract and alum (ALE+Alum) exhibited more beneficial antibacterial activity on test bacteria than with methanolic (MLE+Alum). The susceptibility of these pathogens to the combinations were much 
more pronounced on the Gram negative bacteria thus, Pseudomonas aeruginosa $(21 \mathrm{~mm})$ and Escherichia coli $(20 \mathrm{~mm})$ than on Gram positive, Staphylococcus aureus and Bacillus subtilis (19mm) respectively [12]. The results also revealed that $P$. guajava leaf extracts plus alum could be used as a novel source of antibacterial agent against infections and/or diseases caused by these pathogenic microorganisms. In another study, bioactivities of aqueous, ethanolic and methanolic leaf extracts of Gongronema latifolium in combination with alum against some clinical bacterial pathogens were investigated by disc diffusion (DD) and AWD respectively. Methanolic leaf extract (MLE) had the largest mean DIZs of 14.5 \pm 0.5 and $11.5 \pm 0.0 \mathrm{~mm}$ on Escherichia coli and Salmonella typhi with enhanced bioactivity of $19.5 \pm 0.7$ and $17.5 \pm 0.7 \mathrm{~mm}$ against Bacillus subtilis, Salmonella typhi and Pseudomonas aeruginosa on exposure to alum by DD and AWD methods respectively. However, aqueous leaf extract (ALE) and ethanolic leaf extract (ELE) and their combinations depicted appreciable antibacterial activity on the pathogens but incomparable to MLE. Low MIC values of $<0.05$ to $0.2 \mathrm{mg} / \mathrm{ml}$ on the bacteria with MLE and ALE, suggests their potency and broad spectrum activity [13].

Synergism with inorganic compound

Hydrogen peroxide $\left(\mathrm{H}_{2} \mathrm{O}_{2}\right)$ and potash alum (PA) are considered important for wide range of biological activities including microbial disinfection. Susceptibility test of five bacterial isolates; Enterococcus faecalis, Enterococcus faecium, Escherichia coli, Staphylococcus aureus and Klebsiella pneumoniae against $\mathrm{H}_{2} \mathrm{O}_{2}$ and PA alone and in combination showed concentration dependent and incubation dependent effect. $\mathrm{H}_{2} \mathrm{O}_{2}$ bacterial susceptibility trend was $E$. coli $>$ K. pneumoniae $>$ S. aureus $>$ E. faecium $>$ E. faecalis and PA was $K$. pneumoniae $>S$. aureus $>$ E. faecalis $>$ E. coli $>$ E. faecium at highest tested concentration $(35 \mathrm{mg} / \mathrm{ml})$ and $24 \mathrm{hr}$ of incubation period. Comparatively, antibacterial activity was higher with $\mathrm{H}_{2} \mathrm{O}_{2}$ than PA, however in the order of $24 \mathrm{hr}>48 \mathrm{hr}>72 \mathrm{hr}$. Both $\mathrm{H}_{2} \mathrm{O}_{2}$ and PA depicted larger inhibition zones at highest concentration than positive control azithromycin (AZI) against E. faecalis, E. faecium and $S$. aureus at all incubation periods. Moreover, $\mathrm{H}_{2} \mathrm{O}_{2}$ and PA in combination (1:1) showed increased zone of inhibition than PA alone (against all bacteria), $\mathrm{H}_{2} \mathrm{O}_{2}$ alone (against $E$. faecalis and E. faecium) and, AZI (against E. faecalis, E. faecium and S. aureus) without increasing final concentration [14].

\section{Synergism with antibiotics}

Most E. coli strains are harmless and colonize the gastrointestinal tract of humans and animals as normal flora. This study on bacterial susceptibility found all isolates resistant to several antibiotics tested and considered multi-drug resistant (MDR). With alum, inhibitory effect was highest on E. coli and C. albicans (resistance to most antibiotics) at concentrations of $16 \%$ and $20 \%$ and other isolates were sensitive at $20 \%$. The combination of alum with antibiotics (tetracycline and cefotaxime) was highly effective than antibiotic combination, and the effect of alum with antibiotic was stronger than a single dose. Alum alone had an inhibitory zone of $38 \mathrm{~mm}$ on $E$. coli but $46 \mathrm{~mm}$ in combination with cefotaxime and $40 \mathrm{~mm}$ with tetracycline [15]. Synergistic antibacterial interaction between alum and antibiotics were more beneficial and dose dependent.

\section{Antifungal effect of alum}

Mecteau., et al. [16] have also reported the inhibition of spore germination and/or mycelial growth of Fusarium solani var. coeruleum, Alternaria alternate, Botrytis cinerea, Phytophthora erythroseptica, P. infestans, Verticillium albo-atrium and $V$. dahlia by PAS and other aluminium salts which was linked to the generation of an acidic micromilieu which caused cell toxicity [17]. In another development, fungal isolates such as Aspergillus niger, A. flavus, Fusarium sp, Penicillium sp, Rhizopus stolonifer, Geotrichum candidium and Saccharomyces cerevisiae from deteriorating tomatoes were subjected to In vitro activity with $1 \%$ PA (w/v) concentration by AWD. G. candidum had the highest DIZ (9.0mm (29.0\%) followed by A. niger (8.0 mm (25.8\%) and 7.0mm (22.6\%) for Fusarium and Penicillium species respectively. R. stolonifer was not inhibited [18]. However, exposure of postharvest spoilage tomatoes to PA prior to consumption would enhance food safety and some spoilage and toxigenic or opportunistic pathogens would be eliminated.

\section{Synergism with plant extract}

Antifungal activity of crude Turmeric rhizome extracts and in combination with alum against five (5) fungal species were determined using (DD) and (AWD) methods respectively. The extracts and alum were active against all the test microbes and dose-dependent. Strong antimycotic activity occurred with alum in the order Aspergillus terreus $(17.5 \pm 1.0 \mathrm{~mm})>$ A. flavus $(17 \pm 1.0 \mathrm{~mm})>S$. cerevisiae $(14 \mathrm{~mm})>C$. albicans $(12 \pm 1.0 \mathrm{~mm})$ by DD respectively. With AWD, alum demonstrated highest antimycotic activity on $A$. terreus $(35 \pm 1.0 \mathrm{~mm})>$ Penicillium crystallium and A. flavus $(33.0 \mathrm{~mm})>S$. cerevisiae $(24.0 \mathrm{~mm})$ [19]. However, enhancement of antifungal potential of Turmeric rhizome extracts was achieved by incorporation of alum, so, more research with safe, natural products to provide an 
alternative to antifungal treatment of diseases of plants, animals and humans is hereby advocated.

Antimicrobial activity of alum resulting in preservation of fruits

Growers and retailers of climacteric plants like banana in tropical countries are beset by rapid ripening of their products. Crown rot in fruits is caused by a broad unspecific and opportunistic fungal parasitic complex; Lasiodiplodia theobromae, Colletotrichum musae, Fusarium spp., Verticillium spp. and Cephalosporium spp [20]. It was identified that eugenol was the most effective antifungal component of basil oil in inhibiting conidial germination of C. musae and Fusarium proliferatum, in vitro. Both Ocimum basilicum and eugenol inhibited appressoria formation by $C$. musae and changed the selective permeability of conidial membranes [21]. Alum, indicated fungicidal properties against Embul banana fruit pathogens In vitro but controlled crown rot disease severity (In vivo) successfully irrespective of stage of maturity. Further, integrated treatment of alum and basil oil (at $0.16 \%$ or $0.2 \%$ ) with MAP at optimum temperature of $12-14^{\circ} \mathrm{C}$ controlled the crown rot disease when harvested at 85 day maturity and extended storage life up to 32 days. Application of $1 \%$ alum and basil oil spray treatment $(0.16 \%$ or $0.20 \% \mathrm{v} / \mathrm{v})$ in combination with MAP and cold storage could be control crown rot disease on three maturity levels of 80,85 and 90 days to lengthen their storage life up to 32 days. However, such integrated novel, eco-friendly treatments could be exploited and utilized in commercial scale sea shipment of banana to various destinations requiring greater than 30 days of voyage [22].

Fruit at green stage- 1 which were also treated with 1\% Alum and $1 \%$ Benomyl for 10 minutes simultaneously, vacuum packed in LDPE bag and stored resulted in extension of shelf life [23]. Additionally, the use of PAS in delatexing baths is important for cosmetic appearance, control of crown rot pathogens, promotes the healing of the cutting wounds and quality of bananas as well as extension of the shelf-life of Philippine banana-lakatan species from 5 - 8 to 17.6 days using non expensive method, like the immersion of bananas for 10,20 or 30 minutes in $50 \mathrm{~g} / \mathrm{L}$ PAS [24]. The antioxidant content of alum oxidizes ethylene to carbon dioxide and water, limiting the increase in ethylene that speeds up fruit ripening. In areas without electricity and refrigeration, banana farmers could prolong the ripening process thereby increasing profit.
In a related study, alum was suggested as an alternative fungicide because of its efficacy in the control of crown disease of Cavendish banana and has also been used to extend the shelf life of tomatoes [25] and strawberry fruit using different concentration of sucrose solution and potash alum stored at ambient temperature alum depicted better results in $30^{\circ}$ and $40^{\circ}$ Brix sucrose solution concentration and highly acceptable both physicochemically and organoleptically during 90 days of storage [26].

Antimicrobial activity of alum resulting in preservation of seafood

Microbiological analysis of raw oysters revealed that they harbour a broad spectrum of bacteria; Bacillus spp., Pseudomonas aeruginosa, Staphylococcus aureus, Streptococcus spp., Vibrio spp., Proteus spp., Micrococcus spp., Lactobacillus spp. and Corynebacterium spp. Oysters exposed to $1.0 \%(\mathrm{w} / \mathrm{v}$ ) PAS had fewer (five) bacterial genera at $\mathrm{pH}$ values of between 3.2 and 4.0 than the control. The sensory and organoleptic attributes of all samples decreased significantly $(\mathrm{p}<0.05)$ and became unacceptable after one day but PAS-preserved samples remained highly acceptable throughout the storage period of 3days [5]. Thus, the PAS-treatment is highly recommended for shelf-life extension of oysters.

\section{Alum: In food processing}

PAS has been used in food processing to produce crisp cucumbers and water melon-rind pickles as well as maraschino cherries, where the aluminium ion strengthen the fruits' cell wall pectins [27]. It is also used in processing potato starch and noodle, where honeycomb structure is destroyed, number of internal pores and average areas are decreased with increase in crystallisation and ionic bond being dominant in the potato starch interaction system [28]. Increase in solubility, gelatinisation temperature and enthalpy as well as decrease in swelling power and light transmittance of stored paste, viscosity and textural parameters were also influenced. However, the high ionic strength and water-binding capacities of $\mathrm{Al}^{3+}, \mathrm{K}^{+}$and $\mathrm{SO}^{2-}$ point to being the main factors for these observed changes $[27,28]$. Alum has also extended the shelf life of African breadfruit (Treculia africana) seed and improved the functional properties and proximate composition of Asparagus bean (Vigna sesquipedalis) [29,30].

\section{Sundry applications}

Traditional medicine

Potash alum is frequently used topically and internally in tradi- 
tional systems of medicine including Ayurveda, where it is called phitkari or saurashtri or Sphatika bhasma, and traditional Chinese medicine, where it is called ming fan [2] more reports have been earlier documented [1]. A clinical study carried out to find out the efficacy of Tankana (Purified borax powder) and Sphatika bhasma (purified potash alum) with Madhu pratisarana in Tundikeri (Chronic Tonsillitis) on 30 patients confirmed that both drugs Tankana bhasma with Madhu pratisarana and Sphatika bhasma with Madhu pratisarana on Tundikeri had significant effect [31]. However, in overall assessment, the efficacy of Tankana bhasma pratisarana is more significant than Sphatika bhasma pratisarana in the management of chronic tonsillitis.

\section{Cosmetics}

Potash alum (PA) has different traditional application such as deodorant and astringent to prevent bleeding and accelerate healing. In the pharmaceutical and cosmetic industries the safety and efficacy of this traditionally used natural products had improved. PA formulations have found applications as deodorant lotion, cream and gels. The activity of PA against axillaries normal microbiota was due to its bacteriostatic property [32]. Alum shown excellent inhibitory effects on tested bacteria with lowest MIC value of alum against Corynebacterium xerosis (ATCC BAA-1293) as 1.88 $\mathrm{mg} / \mathrm{mL}$. Micrococcus luteus (ATCC 49732), Bacilus subtilis (ATCC 19659) and Staphylococcus epidermidis (ATCC 14990) with higher MIC of 3.75 at 5.00 and $7.50 \mathrm{mg} / \mathrm{mL}$ respectively. The study bacteria were completely inhibited at a concentration of $7.50 \mathrm{mg} / \mathrm{mL}$ [7]. Indicating that alum has excellent antibacterial activity against axillary malodour-producing bacteria and is recommended to be used either directly by topical application or as an active ingredient in deodorants and antiperspirants.

\section{Management of foot odour}

The management of foot odour due fungal and bacterial pathogens had been a serious challenge for pharmaceutical companies. A homemade topical powder mix of chalcanthite, alum, and clove was practically applied on many people, with remarkable success in the treatment of foot odour. Total recovery was achieved within 3 days of administration with no side effects [33].

\section{Alum as adjuvant}

Alum is the most widely used vaccine adjuvant and the first human adjuvant, which promotes a strong humoral response and is widely used in viral vaccines [34] but its mechanism of action re- mains largely unknown. A recent study shows that alum interacts directly with membrane lipids on the surface of dendritic cells, triggering signalling cascades that promote $\mathrm{CD} 4{ }^{+} \mathrm{T}$ cell activation and humoral immune response [5].

\section{Periodontology}

The effect of alum on gingival health, cytotoxicity and safety for oral human health had been earlier reported [9]. PA has demonstrated activity against oral microbiota. More recently, alum's activity against cariogenic streptococci, normal oral flora and periodontal pathogens has significantly reduced the colonization ability of streptococci on enamel surfaces and decreasing the colloidal stability of oral bacteria [35]. Clinical trials in plaque and bleeding patients at different PA concentrations; 5, 10 and 15mg/100mL for 15 and 30 days respectively indicated significant reductions in bleeding. The reduction was dose-dependent and had significant correlation with the date the bleeding reduced to zero and there was significant difference $(\mathrm{P}<0.005)$ between the three concentrations with $15 \mathrm{mg} / 100 \mathrm{~mL}$ being the most powerful [36]. Candida albicans, Streptococcus mutans and Pseudomonas aeruginosa, are aetiologic agents of oral thrush and mouth ulcers. These isolates were subjected to sensitivity test to two plant extracts of Syzygium aromaticum (Clove) and Peganum harmala as well as Alum, alone and in combination treatments. The study showed that Clove and $P$. harmala had high antimicrobial activity against all isolates even at low concentrations; MIC values were $0.25 \mathrm{mg} / \mathrm{mL}$ and $0.5 \mathrm{mg} / \mathrm{mL}$ for the extracts respectively and $10.0 \mathrm{mg} / \mathrm{mL}$ for Alum. Synergistic effect was accentuated with $P$. harmala extract and Alum than with Clove and Alum [37]. Therefore, P. harmala, Clove or Alum could be used for the control of these organisms and prevent oral thrush and mouth ulcer by washing the mouth with these substances or putting them on lesions for some period and rinsing.

\section{Alum: a component of anti haemorrhoid injection therapy}

A quick hemostatic effect, sclerosing and shrinkage of hemorrhoids, can be attained when internal haemorrhoids are treated by using injection therapy with aluminum potassium sulphate and tannic acid (ALTA), the outcomes of treatment may be similar to those of a hemorrhoidectomy. Accordingly, sufficient understanding of the treatment mechanism of ALTA injection and repeated training for injection are required for effective use of the ALTA treatment [38]. Recently, a rare case of acute liver injury developed after an internal hemorrhoid treatment with the aluminum potassium sulphate and tannic acid (ALTA) regimen. The acute liver in- 
jury was classified clinically as hepatocellular and pathologically as cholestastic. Fluid replacement for two weeks after hospitalization improved the liver injury [39]. ALTA therapy involves injecting chemicals into the submucosa, from the rectum to the anus, and this is the first description of a case that developed a severe liver disorder after this treatment; hence, an analysis of future cases as they accumulate is desirable.

\section{Sundry applications}

\section{Alum as catalyst in organic transformational reactions}

Alum has been a veritable/useful catalyst in organic transformational reactions under heating/reflux and microwave irradiation resulting in myriads of synthetic derivatives with pharmacological and pharmaceutical applications [6,40]. Literature survey reveals that it serves as an efficient acid catalyst in implementing a galaxy of organic transformations and has attracted the attention of the synthetic chemists due to its inherent catalytic proficiency, low-cost, non-toxicity, and eco-friendliness.

\section{Petrol and diesel pollution control}

The use of fossil fuels such as petroleum can have a negative impact on earth's biosphere as pollutants, oil spills and greenhouse gases released may result in global warming, thus, influencing the integrity of the ecosystem. PA effect have been proven to play a vital role in development of non-pollutant petrol and diesel because it reduces exhaust emissions, auto ignition temperature, gives more mileage and more engine efficiency, affects the cetane number in diesel (higher cetane number indicates that the fuel ignites more readily when sprayed into hot compressed air) and complete combustion [2].

\section{Alum: A component of soap for firecrackers}

Firecrackers' manufacturing involves mixing of various chemicals. Moreover, it leads to lot of health issue to the workers like respiratory disorders, skin problems, damage to kidney, mental impairment and eye irritation, also it can cause cancer. To overcome these hazardous problems, a soap for the affected people which incorporates organic solvent (ethanol) with the mixture of alum and sodium lauryl sulphate salts had been formulated [1,41]. Apart from having a cost effective product with longevity and with good quality, alum functions as an antimicrobial agent to destroy pathogens which may infect firecrackers.

\section{Treatment of poultry litter}

Microbial mineralization of urea and uric acid in poultry litter results in the production of ammonia, which can lead to decreased poultry performance, malodorous emissions, and loss of poultry litter value as a fertilizer. After bioassay, alum treatment reduced the total bacterial population by $50 \%$ and bacterial urease producers by $90 \%$ within $4 \mathrm{wk}$. In contrast, at $16 \mathrm{wk}$ after alum treatment, the fungal population was three orders of magnitude higher in alumtreated litter than in nontreated litter $\left(3.5 \pm 0.8 \times 10^{7}\right.$ cells $\mathrm{g}^{-1}$ litter and $5.5 \pm 2.5 \times 10^{4}$ cells $\mathrm{g}^{-1}$ litter, respectively) [42]. The decrease in $\mathrm{pH}$ produced by alum treatment is believed to inhibit bacterial populations and favour growth of fungi that may be responsible for the mineralization of organic nitrogen in alum-treated litters.

Domestic water treatment and removal of phosphorus from waste water

A value of $0.2 \mathrm{mg} / \mathrm{l} \mathrm{PA}$ in drinking water is recommended by WHO based on aesthetic consideration for decontamination of water (WHO, 1984). Careful operation of filtration or any other process is mandatory for successful treatment of water to obtain both an aesthetically acceptable product and effective disinfection [43]. Additionally, pure alum, iron chloride and iron sulphate were much more efficient in phosphorus removal than the spent alum sludge whereas with calcium hydroxide, phosphorus removal was very low in $\mathrm{pH}$. Specifically, orthophosphate were totally removed by alum using $15 \mathrm{mg} / \mathrm{L}$ as $\mathrm{Al}$, by alum sludge using $75 \mathrm{mg} / \mathrm{L}$ as $\mathrm{Al}$ whereas calcium hydroxide $\mathrm{P}$ removal was actually zero. Finally, it was reported that water proved to be effective not only to remove phosphorus but turbidity and COD as well [44]. Gamage., et al. [45] has also made similar presentation on the beneficial use of alum to remove phosphorus from Municipal waste water.

\section{Mordant in textile industry}

Beberine is a cationic colorant present in the extract of Berberis vulgaris root used as a natural dye for wool. Mordanting with copper sulphate, alum and Potassium dichromate before dyeing increased the dye uptake and fastness properties as well as antibacterial property of the samples [46]. Recently, another worker reported the use of peanut red skin (Arachis hypogaea L.) colourant extract on wool fabric with alum and ferrous sulphate as mordants and improved the fastness properties of the dyed fabrics toward perspiration, rubbing, washing and light [47]. Since a high amount 
of mordant is absorbed by wool fibres, minimal amount of mordant is expelled by the waste water, the process can be considered environmentally friendly with low pollution level.

\section{Conclusion}

Alum demonstrates strong antimicrobial activity against both Gram positive and Gram negative bacteria as well as against yeasts and moulds. This activity is dose and incubation period dependent and much more accentuated in synergism with plant extracts, inorganic substances or antibiotics. As with any generally recognized as safe (GRAS) additives when the recommended dose/ concentration is applied, so it is with alum. Abuse may result in toxicity and other complications. It is an excellent agent for the biotransformation of several organic and inorganic substances as well as for medicinal, cosmetic, pharmacological, pharmaceutical and food systems. However, further research are necessary to elucidate its mechanism of action, positive consequences of overdose and antiviral action.

\section{Bibliography}

1. Ali A., et al. "Shibb-e-yamani (alum) a unique drug and its utilization in Unani medicine: A physicochemical and pharmacological review". International Journal of Research in Ayurveda and Pharmacy 8. 2 (2017): 228-233.

2. Sundar AS. "Petrol and Diesel Pollution Control by Potassium alum". International Journal of Advancements in Research and Technology 2.2 (2013): 1-12.

3. Birnin-Yauri AU and Aliyu M. "Synthesis and Analysis of Potassium Aluminium Sulphate (Alum) from Waste Aluminium Can". International Journal of Advanced Research in Chemical Science 8 (2014): 1-6.

4. Efiuvwevwere BJO and Amadi LO. "Effects of Preservatives on the Bacteriological, chemical and sensory qualities of mangrove oyster (Crassostrea gasar) harvested from the Niger Delta Region Nigeria". British Journal of Applied Science and Technology 5.1 (2015): 76-84.

5. Mbow M., et al. "Alum's adjuvant action: grease is the word". Nature Medicine 17 (2011): 415-416.

6. Brahmachari G., et al. "Alum (KAl (SO4)2.12H20) - An Ecofriendly and Versatile Acid-catalyst in Organic Transformations: A Recent Update". Current Green Chemistry 6.1 (2019): 12-31.
7. Al-Talib H., et al. "Potassium Aluminium Sulphate (Alum) Inhibits Growth of Human Axillary Malodor-Producing Skin Flora In Vitro". Journal of Clinical and Health Science 1.1 (2016): 59-63.

8. Putt MS and Kleber CJ. "Effect of aluminum concentration on dental caries formation in the rat". Oral Diseases 1.2 (1995): 80-85.

9. Shahriari R., et al. "In vitro Study of Concentration-effect and Time-course pattern of white Alum on Escherichia coli 0157:H7 Growth". African Journal of Traditional, Complementary and Alternative Medicines 14.2 (2017):311-318.

10. Photos-Jones E. "From mine to apothecary: an archaeo-biomedical approach to the study of the Greco-Roman lithotherapeutics industry". World Archaeology 50.3 (2018): 418-433.

11. Amadi LO and Ngerebara NN. "Susceptibility Profiles of Alum on Bacteria Isolated from Shellfish Bivalve Oyster". International Journal of Current Microbiology and Applied Sciences 6.1 (2017): 941-947.

12. Amadi LO., et al. "Synergistic effects of alum and guava (Psidium guajava) leaf extracts on some pathogens from clinical samples". International Journal of Current Research 8.5 (2016):31354-31358.

13. Amadi LO., et al. "Profilistic Study of Bioactivities of Extracts of Gongronema latifolium Incorporated with Alum on some Clinical Bacteria”. International Current Pharmaceutical Journal 6.12 (2018):92-98.

14. Khurshid H., et al. "Antimicrobial properties of hydrogen peroxide and potash alum alone and in combination against clinical bacterial isolates". Pure and Applied Biology 8.4 (2019): 2238-2247.

15. Ali ZM. "Synergistic antibacterial interaction between an alum and antibiotics on some microorganism". Journal of Research in Medical Sciences 2.5 (2018): 47-51.

16. Mecteau MR., et al. "Effect of different salts on the growth and development of Fusarium solani var. coeruleum, a causal agent of potato dry rot". Phytoprotection 89 (2008):1-6.

17. Kolaei EA., et al. "Antifungal activity of aluminium-containing salts against the development of carrot cavity spot and potato dry rot". Annals of Applied Biology 163 (2013): 311-317. 
18. Amadi LO., et al. "Antimycotic Potential of Alum on Postharvest Deterioration of Tomato". Microbiology Research Journal International 29.3 (2019):1-10.

19. Amadi LO., et al. "Bioefficacy of Turmeric Rhizome Extracts with Alum on Microbes: An In vitro Approach". American Journal of Microbiol Research 7. 2 (2019): 51-56.

20. Abd-Alla MA., et al. "Post-harvest treatments for controlling crown rot disease of Williams banana fruits (Musa acuminata L.) in Egypt". Plant Pathology and Quarantine 4.1 (2014): 1-12.

21. Herath $\mathrm{H}$ and Abeywickrama K. "In vitro application of selected essential oils and their major components in controlling fungal pathogens of crown rot in Embul banana". International Journal of Food Science and Technology 43 (2008): 440-447.

22. Abeywickrama K., et al. "An integrated treatment of Basil oil (Ocimum basilicum) and Alum with modified atmosphere to control crown rot disease in embul banana". Tropical Agricultural Research and Extension 12.1 (2009): 24-30.

23. Jadhav PB., et al. "Extending the shelf-life of banana cv. "Grande Naine" using a cold room (Ecofrost)". International Journal of Scientific Research and Reviews 5.7 (2018): 71-75.

24. Acero LH. "Ascorbic Acid and Potassium Aluminum Sulphate Solutions in Shelf-Life of Philippine Banana Lakatan (Musa acuminata) Species". International Journal of Food Engineering 1.1 (2015): 34-38.

25. Siriwardana H., et al. Efficacy of alum treatment and vacuum packaging in controlling crown rot disease of Cavendish banana Journal of Faculty of Graduate Studies, University of Kelaniya, Sri Lanka 5 (2016a):7-23.

26. Zeb A., et al. "Postharvest evaluation of Strawberry fruit preserves in different concentration of Sucrose solution and Potash Alum stored at ambient temperature". International Journal of Food Sciences and Nutrition S13.001 (2015): 1-8.

27. Wenhao L., et al. "Effect of potassium alum addition on physicochemical, pasting, thermal and gel texture properties of potato starch". International Journal of Food Science and Technology 46 (2011):1621-1627.

28. Li Z., et al. ". Effect of Potassium alum addition on the quality of Potato starch noodle". Journal of Food Science and Technology 56.6 (2019): 2932-2939.

29. Ihediohanma NC. "Effect of treatment with alum on the keeping quality of African breadfruit (Treculia africana) seed". $\mathrm{Ni}$ geria Food Journal 27.2 (2009): 129-134.
30. Nwosu JN. "The effects of steeping with chemicals (Trona and Alum) on the functional properties and proximate composition of Asparagus bean (Vigna sesquipedalis)". Nature and Science 8. 9 (2010):111-120.

31. Sahoo I., et al. "Clinical Appraisal on Therapeutic Efficacy of Tankana and Sphatika Bhasma with Madhu Pratisarana in Tundikeri". Journal of Drug Delivery and Therapeutics 9.6 (2019):130-134.

32. Alzomor AK., et al. "Formulation and evaluation of potash alum as deodorant lotion and after shaving astringent as cream and gel". International Current Pharmaceutical Journal 3.2 (2014): 228-233.

33. Baker AG. "Topical Powder Mix of Chalcanthite, Alum, and Clove as an Effective Feet Odor Treatment". ARO-The Scientific Journal of Koya University VI. 2 (2018): 1-6.

34. Doherty MT and Andersen P. "Vaccines for Tuberculosis: Novel Concepts and Recent Progress". Clinical Microbiology Reviews 18.4 (2005): 687-702.

35. Rupesh S., et al. ". Comparative evaluation of the effects of an alum-containing mouthrinse and a saturated saline rinse on the salivary levels of Streptococcus mutans". Journal of Indian Society of Pedodontics and Preventive Dentistry 28.3 (2010):138-144.

36. Hussein AA. "The effects of different concentration of Alum solutions on plaque and bleeding levels". Journal of Pharmaceutical Sciences and Research 11. 3 (2019): 1078-1081.

37. Flayeh RA. "Antifungal Activity of Some Plant Extract and Alum on yeast isolated from mouth lesions". Euphrates Journal of Agriculture Science 2.2 (2010): 1-4.

38. Lim SW. "Aluminum Potassium Sulphate and Tannic Acid Injection for Hemorrhoids". Journal of the Korean Society of Coloproctology 28.2 (2012): 73-77.

39. Yoshikawa K., et al. "Liver injury after aluminum potassium sulphate and tannic acid treatment of haemorrhoids". World Journal of Gastroenterology 23. 27 (2017): 5034-5040.

40. Zolfigol MA., et al. "Alum as a catalyst for the synthesis of bispyrazole derivatives". Applied Sciences 6.1 (2016): 27.

41. Vishnuvarthanan G., et al. "Augmenting Cleansing Process for Reducing Occupational Hazards Experienced by Labours Handling Pyrotechnical Chemicals in Firecracker Units". International Journal of Innovative Technology and Exploring Engineering 9.2S2 (2019):921-925. 
42. Cook KI., et al. "Effect of Alum Treatment on the Concentration of Total and Ureolytic Microorganisms in Poultry Litter. Technical Reports: Waste Management". Journal of Environmental Quality 37 (2008):2360-2367.

43. Dutta S., et al. "In vitro antimicrobial activity of potash alum". Indian Journal of Medical Research 104 (1996):157-159.

44. Georgantas DA and Grigoropoulou HP. “Phosphorus removal from synthetic and municipal wastewater using spent alum sludge". Water Science and Technology 52.10-11 (2005): 525532.

45. Gamage V., et al. "Removal of Phosphorus from Municipal Wastewater" Master of Philosophy (Civil Engineering) Thesis". Curtin University (2016).

46. Haji A. "Antibacterial Dyeing of Wool with Natural Cationic Dye Using Metal Mordants". Materials Science (Medžiagotyra) 18.3 (2012): 267-270.

47. Helmy HM., et al. "Antimicrobial activity of Dyed wool fabrics with Peanut red skin extract using different heating techniques. Egypt J. Chem. Vol. 60. Special Issue. The 8 Int. Conf. Text. Res. Div., Nat. Res. Centre, Cairo (2017): 103-116.

\section{Assets from publication with us}

- Prompt Acknowledgement after receiving the article

- Thorough Double blinded peer review

- Rapid Publication

- Issue of Publication Certificate

- High visibility of your Published work

Website: https://www.actascientific.com/

Submit Article: https://www.actascientific.com/submission.php

Email us: editor@actascientific.com

Contact us: +919182824667

Citation: Lawrence O Amadi. "A Review of Antimicrobial Properties of Alum and Sundry Applications". Acta Scientific Microbiology 3.4 (2020): $109-117$. 